$\overline{\text { Note }}$

\title{
Rapid Identification of Emetic Bacillus cereus by Immunochromatography
}

\author{
SHIGEKO UEDA*, AND YOSHIHIRO KUWABARA \\ Laboratory of Hygiene, Kagawa Nutrition University, 3-9-1, \\ Chiyoda, Sakado-shi, Saitama 350-0214, Japan \\ Received 14 October, 2010/Accepted 6 December, 2010
}

\begin{abstract}
The immunochromatographic assay, which targets a marker protein co-expressed during the synthesis of cereulide by an emetic Bacillus cereus strain, was used for easily, rapidly and specifically identifying the emetic strains among $B$. cereus strains from various materials associated with food poisonings. All 50 of the emetic strains showed a positive reaction to the assay, but all 50 diarrheal strains had a negative reaction. The bacterial counts of $10^{8} \mathrm{cfu} / \mathrm{ml}$ in enrichment broth and $10^{\circ} \mathrm{cfu} / \mathrm{ml}$ in food-containing enrichment were required for the identification of emetic $B$. cereus. The present assay could identify easily and specifically the emetic type of $B$. cereus within $\mathbf{3 0} \mathrm{min}$ by a pure culture without special techniques and instruments.
\end{abstract}

Key words : Bacillus cereus/Emetic toxin/Immunochromatography.

Bacillus cereus is recognized as the etiological agent of two distinct food poisoning syndromes: the diarrheal-type and the emetic type (Kramer and Gilbert, 1989). In Japan, most outbreaks of B. cereus food poisonings are the emetic type due mostly to the ingestion of rice dishes. The $B$. cereus -emetic toxin has been assayed by determining the vacuolation induced in HEp-2 cells as reported by Hughes et al. (1988). Since then, a variety of bioassays and chemical assays have become available for the detection of cereulide (Finlay et al., 1997; Andersson et al., 2004; Haggblom et al., 2002; Kawamura-Sato et al., 2005). Fricker et al. (2007) developed a real time PCR assay which targeted the cereulide synthetase genes. An immunochromatographic assay, using monoclonal antibodies prepared against a specific antigen target, has been available for detecting rapidly and simply some pathogenic microbes and microbial toxins (Engler et al., 2002; Xiulan et al., 2005; Kitao-Ando et al., 2010). The emetic toxin is produced in the cellfree supernatant of the bacterial culture, and has now been identified as a dodecadepsipeptide composed of three repeated sequences of four amino and/or

${ }^{*}$ Corresponding author. Tel : +81-49-282-7343, Fax $:+81$ 49-282-3717, E-mail:ueda (a) eiyo.ac.jp oxy-acids, and is termed cereulide (Agata et al., 1994). A marker protein is co-expressed during the synthesis of cereulide by a nonribosomal peptide synthetase (Ehling-Schultz et al., 2005, 2006), and is released into the cell-free supernatant. In the present study, an immunochromatographic assay which targeted the marker protein was examined as a method for the rapid and simple identification of the emetic $B$. cereus strains isolated from various sources.

Fifty emetic type $B$. cereus strains from a variety of food and faecal samples associated with $B$. cereus food poisoning cases were used in the immunochromatographic assay. It had already been confirmed that these strains induced vacuolation in HEp-2 cells (Ueda et al., 1993). In addition, 50 strains of $B$. cereus, which did not produce the emetic toxin, and other gram-positive and negative bacteria were used as the reference bacterial strains. Each bacterial strain was incubated in 10\% skim milk (Difco), BHI broth (BBL), trypticase soy broth (TSB) (BBL) and/or casein hydrolysate-yeast extract broth (CHYEB) at $35^{\circ} \mathrm{C}$.

The assay was carried out by using an immunochromatographic device (Singlepath ${ }^{\circledR}$ Emetic Tox Mrk, Merck) based on gold-labeled antibodies specific to the marker protein co-expressed during 
TABLE 1. Results of immunochromatographic assays of several B.cereus strains cultivated in various enrichment media at $35^{\circ} \mathrm{C}$ for $16 \mathrm{~h}$.

\begin{tabular}{|c|c|c|c|c|c|c|c|c|c|c|}
\hline \multirow{2}{*}{$\begin{array}{l}\text { Enrichment } \\
\text { broth }\end{array}$} & \multirow{2}{*}{ Strain No. } & \multirow{2}{*}{ Starch $^{11}$} & \multicolumn{2}{|c|}{ Detection bands } & \multirow{2}{*}{$\begin{array}{l}\text { Emetic } \\
\text { toxin }^{2}\end{array}$} & \multirow{2}{*}{ Strain No. } & \multirow{2}{*}{ Starch $^{11}$} & \multicolumn{2}{|c|}{ Detection bands } & \multirow{2}{*}{$\begin{array}{l}\text { Emetic } \\
\text { toxin }^{22}\end{array}$} \\
\hline & & & Control & Diagnostic & & & & Control & Diagnostic & \\
\hline & \multicolumn{6}{|c|}{ Emetic type strains } & \multicolumn{4}{|c|}{ Diarrheal type strains } \\
\hline \multirow{3}{*}{$\mathrm{BHI}$} & 2 & - & + & + & 40 & 6 & + & + & - & - \\
\hline & 9 & - & + & + & 80 & 18 & + & + & - & - \\
\hline & 13 & - & + & + & 320 & 39 & + & + & - & - \\
\hline \multirow{3}{*}{$\mathrm{TSB}^{3)}$} & 2 & - & + & + & 40 & 6 & + & + & - & - \\
\hline & 9 & - & + & + & 80 & 18 & + & + & - & - \\
\hline & 13 & - & + & + & 320 & 39 & + & + & - & - \\
\hline \multirow{3}{*}{$\begin{array}{l}\text { 1\%Glucose } \\
-\mathrm{CHYEB}{ }^{4)}\end{array}$} & 2 & - & + & + & 40 & 6 & + & + & - & - \\
\hline & 9 & - & + & + & 80 & 18 & + & + & - & - \\
\hline & 13 & - & + & + & 320 & 39 & + & + & - & - \\
\hline \multirow{3}{*}{$\begin{array}{l}\text { 10\%Skim } \\
\text { milk }\end{array}$} & 2 & - & + & + & 40 & 6 & + & + & - & - \\
\hline & 9 & - & + & + & 80 & 18 & + & + & - & - \\
\hline & 13 & - & + & + & 320 & 39 & + & + & - & - \\
\hline
\end{tabular}

1) Ability of starch hydolysis; 2) Highest dilution to cause vacuolation in HEp-2 cells;

3) Trypticase Soy Broth; 4) Casein Hydrolysate Yeast Extract Broth.

TABLE 2. Growth of emetic strains of B.cereus in $10 \%$ skim milk and results of the immunochromatographic assay.

\begin{tabular}{|c|c|c|c|c|c|c|}
\hline \multirow{2}{*}{$\begin{array}{l}\text { Incubation } \\
\text { time (h) }\end{array}$} & \multirow{2}{*}{$\begin{array}{l}\text { B.cereus } \\
\text { counts }{ }^{1)}\end{array}$} & \multicolumn{2}{|c|}{ Detection bands } & \multirow{2}{*}{$\begin{array}{l}\text { B.cereus } \\
\text { counts }^{1)}\end{array}$} & \multicolumn{2}{|c|}{ Detection bands } \\
\hline & & Control & Diagnostic & & Control & Diagnostic \\
\hline & \multicolumn{3}{|c|}{$<$ strain $9>$} & \multicolumn{3}{|c|}{$<$ strain 13> } \\
\hline 0 & 2.1 & + & - & 2.1 & + & - \\
\hline 2 & 2.0 & + & - & 2.1 & + & - \\
\hline 6 & 3.7 & + & - & 4.1 & + & - \\
\hline 8 & 4.2 & + & - & 5.7 & + & - \\
\hline 16 & 8.7 & + & + & 8.8 & + & + \\
\hline 24 & 8.8 & + & + & 9.0 & + & + \\
\hline 48 & 8.8 & + & + & 8.8 & + & + \\
\hline
\end{tabular}

1) The bacterial counts were expressed as log of $\mathrm{CFU} / \mathrm{ml}$.

the production of $B$. cereus emetic toxins. In the assay, $200 \mu \mathrm{l}$ of the bacterial culture or suspension was added into the bottom of the microwell of the strip, and a diagnostic band appeared if the strain was emetic-toxigenic, in parallel to a control band. The assay enabled a rapid identification of the emetictoxigenic strain within 30 min after application of the culture sample on the strip.

The immunochromatographic assay was used for the rapid identification of the emetic $B$. cereus strains. After 3 emetic and 3 diarrheal type strains were cultured in 4 enrichment media, containing $\mathrm{BHI}$ broth, TSB, $1 \%$ glucose-CHYEB and $10 \%$ skim milk at 35 ${ }^{\circ} \mathrm{C}$ for $16 \mathrm{~h}$, an aliquot of the culture was used for the assay. In any enrichment broth, the same results were obtained by the assays. All 3 emetic strains (strain 2, 9 and 13) induced the vacuolation in HEp-2 cells and were positive in the assays. However, any of 3 diarrheal strains (strain 6, 18 and 39), which did not induce the denaturation of Hep-2 cells, were negative (Table 1). If the emetic type cells were incubated at $35^{\circ} \mathrm{C}$ for $16 \mathrm{~h}$ in enrichment broth and multiplied above $10^{8} \mathrm{cfu} / \mathrm{ml}$, it was shown that the results of the assays were not dependent on the media. Thus, $10 \%$ skim milk was used as the enrichment medium for $B$. cereus in the subsequent study, and also Szabo et al. (1991) found that milk was an excellent medium for $B$. cereus emetic toxin production.

B. cereus strain 9 and 13 , which possessed a relatively strong vacuolation activity against HEp-2 cells, were inoculated into $10 \%$ skim milk at levels of $10^{2}$ $\mathrm{cfu} / \mathrm{ml}$ and incubated at $35^{\circ} \mathrm{C}$, and the enumeration of the bacterial counts and the assays of the cultures were carried out on the specimens sampled from cultures at 2, 6, 8, 1, 24 and $48 \mathrm{~h}$ after the incubation. Consequently, the bacterial counts of both cultures 
TABLE 3. Responses of some food samples contaminated artificically with emetic type strain of B.cereus in the immunochromatographic assay.

\begin{tabular}{|c|c|c|c|c|c|c|}
\hline \multirow{5}{*}{ Food sample ${ }^{1)}$} & \multirow{2}{*}{\multicolumn{3}{|c|}{$\frac{\text { Sample inoculated with emetic type }}{\text { After cultured for } 16 \mathrm{~h} \text { at } 35^{\circ} \mathrm{C}}$}} & \multirow{2}{*}{\multicolumn{3}{|c|}{ Uninoculated sample }} \\
\hline & & & & & & \\
\hline & \multirow{3}{*}{$\begin{array}{l}\text { B.cereus } \\
\text { counts (log } \\
\text { of CFU/ml) }\end{array}$} & \multirow{2}{*}{\multicolumn{2}{|c|}{$\frac{\text { Immunochromatogram }}{\text { Detection bands }}$}} & \multirow{3}{*}{$\begin{array}{c}\text { B.cereus } \\
\text { counts (log } \\
\text { of CFU/ml) }\end{array}$} & \multirow{2}{*}{\multicolumn{2}{|c|}{$\begin{array}{c}\text { Immunochromatogram } \\
\text { Detection bands }\end{array}$}} \\
\hline & & & & & & \\
\hline & & Control & Diagnostic & & Control & Diagnostic \\
\hline Lettuce & 7.8 & + & - & - & + & - \\
\hline Cabbage & 4.8 & + & - & - & + & - \\
\hline Commercial apple juice & 2.6 & + & - & - & + & - \\
\hline Liquid whole egg & 9.4 & + & + & - & + & - \\
\hline Cow milk & 9.0 & + & + & - & + & - \\
\hline Hamburger steak & 9.4 & + & + & - & + & - \\
\hline Boiled rice & 9.0 & + & - & - & + & - \\
\hline Boiled spaghetti & 9.3 & + & - & - & + & - \\
\hline
\end{tabular}

1) After a level of $10^{2} \mathrm{CFU} / \mathrm{ml}$ of B.cereus strain 13 were inoculated into $9 \mathrm{ml}$ of $\mathrm{BHI}$ broth to which $1 \mathrm{~g}$ or $1 \mathrm{ml}$ of food sample had been added, inoculated samples were incubated for $16 \mathrm{~h}$ at $35^{\circ} \mathrm{C}$ under shaking conditions.

amounted to the order of $10^{8} \mathrm{cfu} / \mathrm{ml}$ after the $16 \mathrm{~h}$ incubation, and then the results of the assays showed positive reaction (Table 2). Therefore, levels above $10^{8} \mathrm{cfu} / \mathrm{ml}$ of $B$. cereus in cultures were required for the identification of the emetic strains in this assay.

In addition, pure cultures of emetic-toxigenic strains were identified within 30 min after the 16-h incubation in an enrichment broth. The growth of an emetic strain of $B$. cereus and the immunochromatographic assay was examined in $\mathrm{BHI}$ broth suspended with several food materials including lettuce, cabbage, egg, milk, hamburger steak, boiled rice or spaghetti. B. cereus strain 13 at a level of $10^{2} \mathrm{cfu} / \mathrm{ml}$ was inoculated into $9 \mathrm{ml}$ of $\mathrm{BHI}$ broth to which $1 \mathrm{ml}$ of $10 \%$ food suspension had been added, and incubated for $16 \mathrm{~h}$ at $35^{\circ} \mathrm{C}$. Although the bacterial counts in the suspension cultures of egg, milk, hamburger steak, rice and spaghetti amounted to $10^{\circ}$ $\mathrm{cfu} / \mathrm{ml}$, the results of the assays were positive in suspensions of egg, milk and hamburger steak only, and negative in those of rice and spaghetti (Table 3 ). This may suggest that an appropriate amount of protein or aminopeptide compounds in the substrate may be required for the production of cereulide synthetase and the marker protein.

The specificity of the assay was examined on $B$. cereus strains from food poisoning cases and commercial foods, and other gram positive and negative bacteria. Fifty strains of emetic toxin producing $B$. cereus and 50 strains of non-emetic toxin producers were incubated in $10 \%$ skim milk at $35^{\circ} \mathrm{C}$ for $16 \mathrm{~h}$, and other bacteria cultured in $\mathrm{BHI}$ broth under the same incubation conditions. All 50 starch-non- hydrolysable $B$. cereus strains that caused vacuolation in HEp-2 cells were found to give positive results in the assay, but all 50 starch-hydrolysable strains that produced diarrheal toxins showed negative results (Table 4 ). In this respect, the assay could selectively identify the emetic strains among $B$. cereus strains from various sources. Other bacterial species cultures containing cells at more than $10^{8}$ $\mathrm{cfu} / \mathrm{ml}$ showed negative results, except enterotoxin A and B producing strains among $S$. aureus (Table 5). Although staphylococcal enterotoxins and $B$. cereus cereulide are emetic toxins similarly, the cereulide biosynthetic system is completely different from that of the staphylococcal enterotoxins. That enterotoxinproducing $S$. aureus strains showed the false-positive results to the assay may be a subject that should be investigated further. However, it is thought that there is no problem practically, as $B$. cereus can be differentiated from $S$. aureus on a selective enrichment agar plate.

In conclusion, it was possible for the immunochromatographic assay to identify easily and specifically the emetic type of $B$. cereus within 30 min by using the pure culture without special techniques and instruments. Thus, the present assay is considered to be available as an alternative method for the identification of emetic $B$. cereus. Similarly, Engler et al. (2002) and Kitao-Ando et al. (2010) reported that in other immunochromatographic assays the particular pathogen was identified within 15 min after clinical specimens containing the pathogenic bacteria were incubated in an enrichment broth. 
TABLE 4. Response of emetic type and diarrheal type strains of B.cereus ${ }^{1)}$ in the immunochromatographic assay.

\begin{tabular}{|c|c|c|c|c|c|c|c|c|c|}
\hline \multirow{2}{*}{$\begin{array}{c}\text { Strain } \\
\text { No. }\end{array}$} & \multicolumn{2}{|c|}{ Detection bands } & \multirow{2}{*}{$\mathrm{ET}^{2)}$} & \multirow{2}{*}{$\mathrm{DT}^{3)}$} & \multirow{2}{*}{$\begin{array}{c}\text { Strain } \\
\text { No. }\end{array}$} & \multicolumn{2}{|c|}{ Detection bands } & \multirow{2}{*}{$E T^{2)}$} & \multirow{2}{*}{$\mathrm{DT}^{3}$} \\
\hline & Control & Diagnostic & & & & Control & Diagnostic & & \\
\hline \multicolumn{10}{|c|}{$<$ Starch non-hydrolysable strains: Emetic type strains $>$} \\
\hline 26 & + & + & 80 & - & 98 & + & + & 80 & - \\
\hline 27 & + & + & 80 & - & 99 & + & + & 20 & - \\
\hline 28 & + & + & 320 & - & 100 & + & + & 80 & - \\
\hline 29 & + & + & 80 & - & 101 & + & + & 40 & - \\
\hline 30 & + & $+(w)^{4)}$ & 30 & - & 102 & + & + & 20 & - \\
\hline 31 & + & + & 40 & - & 103 & + & + & 40 & - \\
\hline 32 & + & $+(w)$ & 180 & - & 104 & + & + & 20 & - \\
\hline 33 & + & $+(w)$ & 180 & - & 105 & + & + & 40 & - \\
\hline 34 & + & $+(w)$ & 80 & - & 106 & + & + & 40 & - \\
\hline 52 & + & + & 40 & - & 107 & + & + & 80 & - \\
\hline 53 & + & + & 40 & - & 108 & + & + & 80 & - \\
\hline 54 & + & + & 320 & - & 109 & + & + & 10 & - \\
\hline 55 & + & + & 320 & - & 110 & + & + & 40 & - \\
\hline 56 & + & + & 40 & - & 111 & + & + & 80 & - \\
\hline 57 & + & + & 40 & - & 112 & + & + & 80 & - \\
\hline 58 & + & + & 160 & - & 113 & + & + & 20 & - \\
\hline 59 & + & + & 80 & - & 114 & + & + & 80 & - \\
\hline 60 & + & + & 160 & - & 120 & + & + & 1280 & - \\
\hline 61 & + & + & 160 & - & 121 & + & + & 1280 & - \\
\hline 62 & + & + & 160 & - & 122 & + & + & 640 & - \\
\hline 63 & + & + & 160 & - & 123 & + & + & 640 & - \\
\hline 64 & + & + & 160 & - & 124 & + & + & 640 & - \\
\hline 65 & + & + & 160 & - & 125 & + & + & 320 & - \\
\hline 66 & + & + & 160 & - & 126 & + & + & 640 & - \\
\hline 97 & + & + & 80 & - & 127 & + & + & 80 & - \\
\hline \multicolumn{10}{|c|}{$<$ Starch hydrolysable strains: Diarrheal type strains $>$} \\
\hline 6 & + & - & - & 2000 & 73 & + & - & - & 200 \\
\hline 8 & + & - & - & 20 & 74 & + & - & - & 20 \\
\hline 15 & + & - & - & 20 & 75 & + & - & - & 200 \\
\hline 18 & + & - & - & 2000 & 76 & + & - & - & 200 \\
\hline 35 & + & - & - & 20 & 77 & + & - & - & 20 \\
\hline 36 & + & - & - & 200 & 78 & + & - & - & 20 \\
\hline 37 & + & - & - & 20 & 79 & + & - & - & 200 \\
\hline 38 & + & - & - & 20 & 80 & + & - & - & 20 \\
\hline 39 & + & - & - & 200 & 81 & + & - & - & 20 \\
\hline 40 & + & - & - & 20 & 82 & + & - & - & 20 \\
\hline 41 & + & - & - & 20 & 83 & + & - & - & 200 \\
\hline 42 & + & - & - & 20 & 84 & + & - & - & 200 \\
\hline 43 & + & - & - & 2 & 85 & + & - & - & 20 \\
\hline 44 & + & - & - & 20 & 86 & + & - & - & 20 \\
\hline 46 & + & - & - & 2000 & 88 & + & - & - & 200 \\
\hline 47 & + & - & - & 2 & 89 & + & - & - & 20 \\
\hline 48 & + & - & - & 200 & 90 & + & - & - & 200 \\
\hline 49 & + & - & - & 2000 & 91 & + & - & - & - \\
\hline 50 & + & - & - & 20 & 94 & + & - & - & 200 \\
\hline 51 & + & - & - & 2000 & 95 & + & - & - & 2 \\
\hline 68 & + & - & - & 200 & 96 & + & - & - & 2000 \\
\hline 69 & + & - & - & 200 & 116 & + & - & - & 200 \\
\hline 70 & + & - & - & 200 & 117 & + & - & - & 200 \\
\hline 71 & + & - & - & 20 & 118 & + & - & - & 200 \\
\hline 72 & + & - & - & 200 & 119 & + & - & - & 200 \\
\hline
\end{tabular}

1) The bacteria were grown for $16 \mathrm{~h}$ at $35^{\circ} \mathrm{C}$ under shaking conditions.

2) Activities of ET (emetic toxin) were assayed with HEp-2 cells.

3) Activities of DT (diarrheal toxin) were assayed with the reversible passive latex agglutination assay kit (Denka Seiken). 4) $+($ w): weak positive reaction. 
TABLE 5. Response of various bacterial species in the immunochromatographic assay.

\begin{tabular}{|c|c|c|}
\hline \multirow{2}{*}{ Species/serovar/type ${ }^{1)}$} & \multicolumn{2}{|c|}{ Detection bands } \\
\hline & Control & Diagnostic \\
\hline \multicolumn{3}{|l|}{ Escherichia coli } \\
\hline 0127:H21 (EPEC) & + & - \\
\hline 0124:HNM (EIEC) & + & - \\
\hline 0157:H7 (VT1,2 producer) (EHEC) & + & - \\
\hline 0157:H7ATCC43888 & + & - \\
\hline 0126:H(-) (VT1 producer) (EHEC) & + & - \\
\hline V517 & + & - \\
\hline IFO3301 & + & - \\
\hline Klebsiella aerogenes & + & - \\
\hline Salmonella Enteritidis & + & - \\
\hline Salmonella Typhimurium & + & - \\
\hline Citrobacter freundii & + & - \\
\hline Vibrio parahemolyticus ${ }^{2)}$ & + & - \\
\hline Aeromonas hydrophila 01 ATCC 7966 & + & - \\
\hline Campylobacter jejuni ${ }^{3)}$ & + & - \\
\hline Yersinia enterocolitica 03 & + & - \\
\hline \multicolumn{3}{|l|}{ Staphylococcus aureus } \\
\hline Enterotoxin A producer & + & + \\
\hline Enterotoxin B producer & + & + \\
\hline Enterotoxin C producer & + & - \\
\hline Enterotoxin D producer & + & - \\
\hline Enterotoxin E producer & + & - \\
\hline Enterotoxin $\mathrm{H}$ producer & + & - \\
\hline TSST-1 producer & + & - \\
\hline Bacillus cereus: Emetic type toxin producer & + & + \\
\hline Bacillus cereus: Diarrheal toxin producer & + & - \\
\hline Bacillus cereus IFO13484 & + & - \\
\hline Bacillus subtilis & + & - \\
\hline Bacillus licheniformis & + & - \\
\hline Bacillus pumilus & + & - \\
\hline Bacillus thuringiensis & + & - \\
\hline Clostridium botulinum typeA & + & - \\
\hline C.perfringens Hobbs 13 & + & - \\
\hline Listeria monocytogenes 4b & + & - \\
\hline
\end{tabular}

1) incubated in $\mathrm{BHI}$ broth.

2) incubated in $3 \% \mathrm{NaCl}-\mathrm{BHI}$ broth

3) incubated under microaerobic conditions

\section{REFERENCES}

Agata, N., Mori, M., Ohta, M., Suwano, S., Ohtani, I., and Isobe, M. (1994) A novel dodecadepsipeptide, cereulide, isolated from Bacillus cereus causes vacuole formation in Hep-2 cells. FEMS Microbiol. Lett., 121, 33-34.

Andersson, M.A., Jaakelainen, E.L., Shaheen, R., Pirhonen, T., Wijnands, L.M., and Salkinoja-Salonen, M.C. (2004) Sperm bioassay for rapid detection of cereulideproducing Bacillus cereus in food and related environments. Int. J. Food Microbiol., 94, 75-83.

Ehling-Schultz, M., Vukov, N., Schultz, A., Shaheen, R., Andersson, M., Martbauer, A., and Scheer, S. (2005)
Identification and partial characterization of the nonrobosomal peptide synthetase gene responsible for cereulide production in emetic Bacillus cereus. Appl. Environ. Microbiol., 71, 105-113.

Ehling-Schultz, M., Fricker, M., Grallert, H., Rieck, P., Wagner, M., and Scheer, S. (2005) Cereulide synthetase gene cluster from emetic Bacillus cereus: structure and location on a mega virulence plasmid related to Bacillus anthracis toxin plasmid pX01. BMC Microbiol., 6, 20.

Engler, K.H., Efstratiou, A., Norn, D., Kozlov, R.S., Selga, I., Glushkevich, T.G., Tam., M., Melnikov, V.G., Mazurova, I.K., Tseneva, G.Y., Titov L.P., and George, R.C. (2002) Immunochromatographic strip test for rapid detection of diphtheria toxin: description and multicenter evaluation in areas of low and high prevalence of diphtheria. J. Clin. Microbiol., 40, 80-83.

Finlay, W.J.J., Logan, N.A., and Sutherland, A.D. (1997) Semiautomated metabolic staining assay for Bacillus cereus emetic toxin. Appl. Environ. Microbiol., 65, 18111812.

Fricker, M., Messelhausser, U., Bush, U., Scherer, S., and Ehling-Schultz, M. (2007) Diagnostic real-time PCR assays for the detection of emetic Bacillus cereus strains in foods and recent food-borne outbreaks. Appl. Environ. Microbiol., 73, 1892-1897.

Haggblom, M.M., Apetroaie, C., Andersson, M.A., and Salkinoja-Salonen, M.S. (2002) Quantitative analysis of cereulide, the emetic toxin of Bacillus cereus, produced under various conditions. Appl. Environ. Microbiol., 68, 2479-2483.

Hughes, S., Barthlomew, B., Hardy, J.C., and Kramer, J.M. (1988) Potential application of a Hep-2 cell assay in the investigation of Bacillus cereus emetic syndrome food poisoning. FEMS Microbiol. Lett., 52, 8-11.

Kawamura-Sato, K., Hirama, Y., Agata, N., Ito, K., Torii, K., Takeno, A., Hasegawa, T., Shimomura, Y., and Ohta, M. (2005) Quantitative analysis of cereulide, an emetic toxin of Bacillus cereus, by using rat liver mitochondria. Microbiol. Immunol., 49, 25-30.

Kitao-Ando, T., Miyoshi-Akiyama, T., and Kirikae, T. (2010) Rapid detection of multidrug-resistant Pseudomonas aeruginosa using immunochromatography. Jpn. J. Bacteriol., 65, 199 (P2-154).

Kramer, J.M. and Gilbert, R.J. (1989) Bacillus cereus and other Bacillus species, in Foodborne Bacterial Pathogens (Doyle, M.P. ed.), p.21-70, Marcel Dekker, New York, NY.

Szabo, R.A., Speirs, J.L., and Akhtar, M. (1991) Cell culture detection and conditions for production of a Bacillus cereus heat-stable toxin. J. Food Prot., 54, 272-276.

Ueda, S. and Kuwabara, Y. (1993) An ecological study of Bacillus cereus in rice crop processing: Putative emetic toxin production by $B$. cereus strains isolated at various stage of the process. J. Antibact. Antifung. Agents, 21, 499-502.

Xiulan, S., Xiaolian, Z., Jian, T., Zhou, J., and Chu, F.S. (2005) Preparation of gold-labeled antibody probe and its use in immunochromatography assay for detection of aflatoxin B1. Int. J. Food Microbiol., 99, 185-194. 